\title{
Heteroosivaikutuksen hyödyntäminen kevätrypsillä
}

Mika Hyövelä

Boreal Kasvinjalostus Oy, Myllytie 10,31600 Jokioinen, mika.hyovela@ boreal.fi

\section{Tiivistelmä}

Kevätrypsien jalostus Suomessa on viime vuosikymmenenä painottunut voimakkaasti laatuominaisuuksien kehittämiseen, erityisesti öljyn rasvahappokoostumuksen muokkaamiseen. Samalla lajikkeiden satoisuuden kehittyminen on vähitellen hidastunut. Rypsin viljelyn ongelmaksi on koettu alhainen ja epävarma sadontuottokyky. Alhaisen sadon taustalla on ollut useimmiten huono taimettuminen ja hidas alkukehitys.

Rapsilla tehdyt kokeet ovat osoittaneet hybridilajikkeiden kehittyvän ja peittävän ruudut nopeammin kuin tavanomaisten lajikkeiden heteroosin ansiosta. Kanadalaisissa kasvihuonekokeissa F1-rypsihybridit ovat tuottaneet keskimäärin noin 15-30 \% paremman sadon kuin niiden vanhempaislinjat. Rypsiltä kuitenkin puuttuu laajempaan käyttöön soveltuva hybridimenetelmä. Rypsillä heteroosivaikutusta voidaan kuitenkin hyödyntää synteettisten lajikkeiden avulla lähes yhtä tehokkaasti kuin F1-hybridiellä. Synteettinen lajike syntyy kahden tai useamman vanhempais linjan vapaan pölyttymisen tuloksena ja muodostuu siten vanhempaislinjan sisäisistä ja linjojen välisistä risteytymistä. Synteettisen lajikkeen muodostuessa kahdesta komponentista, on syn1-sukupolvessa 25 \% kumpaakin vanhempais linjaa ja $50 \%$ hybridisiementä. Nämä suhteet voivat kuitenkin vaihdella riippuen ristiinpölyttymisen osuudesta, vanhempien elinvoimasta, suvunjatkamiskyvystä sekä kukintaaikojen eroista.

Useilla lajeilla heteroosin on todettu kasvavan vanhempaislinjojen geneettisen etäisyyden kasvaessa. Tämän olettamuksen perusteella tutkimukseen valittiin 10 eri taustan omaavaa rypsipopulaatiota sekä maantieteellisen että jalostusalkuperän mukaan. Näiden popula atioiden keskinäiset geneettiset etäisyydet määritettiin molekyyligenetiikan keinoin. Geneettisen etäisyyden perusteella valittiin kolme populaatioparia. Näiden populaatioiden kasviyksilöiden väliset geneettiset etäisyydet (euklidinen etäisyys) määritettiin ja yleinen periyttämiskyky testattiin testiristeytyksin. Testiristeytyksiin valittiin sekä geneettisesti läheisiä että etäisiä yksilöitä. Testiristeytyksistä syntyneet siemenet kylvettiin yhdessä vanhempaispopulaatioiden kanssa pellolle jälkeläistestiruuduille keväällä 2003.

Kasvustosta tehtyjen havaintojen, mittausten ja analysoitujen yksilösatojen perusteella geneettisen etäisyyden ja heteroosin yhteys ei ollut odotetun suoraviivainen. Toisaalta myös kasvukauden olosuhteet olivat poikkeukselliset. Erityisesti kukintavaiheen kuivat ja kuumat olosuhteet haittasivat kasvien normaalia kasvua ja kukintojen pölyttymistä. Tällä kokeella saatiin kuitenkin viitteitä siitä, että synteettisillä lajikkeilla voidaan päästä merkittäviin sadonparannuksiin. Koe osoitti myös vanhempaispopulaatioiden valinnan merkitystä - kaikilla populaatiopareilla ei päästy yhtäläisiin tuloksiin. Yhdellä populaatioparilla lähes kaikki testiristeytysjälkeläistöt tuottivat paremman sadon kuin alkuperäiset populaatiot, mutta toisella populaatioparilla tulos oli täysin päinvastainen. Havaittu vanhempien geneettisen etäisyyden ja ilmenneen heteroosin epälineaarisuus osoittaa, ettei vanhempien valinnassa voida luottaa yksinomaan geneettiseen etäisyyteen vaan valinnassa joudutaan käyttämään myös testiristeytyksiin perustuvaa yleisen periyttämiskyvyn arviointia. Kehittämällä jalostusmenetelmää yhä edelleen ja keskittymällä oikeiden vanhempaispopulaatioiden valintaan voidaan synteettisillä kevätrypsilajikkeilla saavuttaa hybridilajikkeiden edut.

Asiasanat: rypsi, hybridit, sato 


\section{Johdanto}

Kevätrypsien jalostus Suomessa on viime vuosikymmenenä painottunut voimakkaasti laatuominaisuuksien kehittämiseen, erityisesti öljyn rasvahappokoostumuksen muokkaamiseen. Ensin painopiste oli erukahapon osuuden vähentämisessä ja sen jälkeen hyödyllisten rasvahappojen kuten öljy- ja linolihapon lisäämisessä. Samalla lajikkeiden satoisuuden kehittyminen on vähitellen pysähtynyt lähes tasolle, johon se nousi 90-luvun alussa Kulta-lajikkeen tultua markkinoille. Viljelijöiden keskuudessa rypsin viljelyn ongelmaksi on koettu alhainen ja epävarma sadontuottokyky. Epäonnistuneen sadon taustalla on ollut useimmiten huono taimettuminen ja hidas alkukehitys.

Brassica-suvun öljykasvien satoisuutta ja kasvuun lähtöä voitaisiin parantaa huomattavasti nykyisestä hybridilajikkeiden avulla. Falkin (1994) mukaan käsinpölytetyt F1-rypsihybridit tuottivat keskimäärin noin 15-30 \% paremman sadon kuin niiden vanhempaislajikkeet. Schulerin (1991) rypsillä tekemät kokeet osoittivat hybridien aloittavan kukintansa hieman vanhempaislinjoja myöhemmin. Rapsilla tehdyt kokeet osoittivat kuitenkin hybridien kehittyvän ja peittävän ruudut nopeammin kuin vanhempansa (Sernyk \& Stefansson 1983).

Rapsilla on kehitetty useita menetelmiä hybridilajikkeiden tuottamiseksi ja pääosa esim. Kanadassa viljeltävistä rapseista on hybridilajikkeita. Menetelmät F1-hybridien tuottamiseen rypsillä ovat kuitenkin olleet rajoitettuja ja tällä hetkellä kehitettyjen menetelmien jatkokehitys on lähes kokonaan lopetettu rypsin markkina-alueen pienennyttyä voimakkaasti Kanadassa. Lisäksi Kanadassa kehitettyihin käytännössäkin toimiviin menetelmiin on liittynyt siirtogeenisyys ja herbisidiresstenssi. Gallais (1988) on todennut synteettisten lajikkeiden olevan mahdollinen välivaihe tilanteessa, jossa F1-hybridimenetelmiä ei ole käytössä. Synteettisillä lajikkeilla heteroosivaikutusta voitaisiin hyödyntää huomattavasti hybridilajikkeita yksinkertaisemmin ja edullisemmin ilman siirtogeenisyyden tuomia ongelmia. Erona F1-hybrideihin nähden on siementuotantovaiheessa vanhempaiskomponenttien pölyttymisen kontrolloimattomuus sekä käyttösiemenen myöhäisempi sukupolvi.

Määritelmän mukaan lajike on synteettinen, jos: a) syn0 tai alkupopulaatiot muodostuvat pääasiassa valituista vanhemmista, b) vanhempien tai komponenttien lukumäärä on alhainen ja c) vanhemmat ovat tuotettu eristettyinä ja uusi lajike on tuotettu näistä komponenteista (Becker 1989). Synteettinen lajike on syntynyt vanhempien vapaan pölytyksen tuloksena ja muodostuu siten lajikkeiden sisäisistä että lajikkeiden välisistä risteytymistä. Synteettisen lajikkeen muodostuessa kahdesta komponentista, on ensimmäisessä syn1-sukupolvessa $25 \%$ kumpaakin vanhempaislajiketta ja $50 \%$ risteytys- 1 . hybridisiementä. Nämä osuudet voivat kuitenkin vaihdella riippuen ristiinpölyttymisen määrästä, vanhempien elinvoimasta, suvunjatkamiskyvystä sekä kukinta-aikojen eroista (Falk 1998).

Syn1-sukupolven synteettiset lajikkeet tuottivat kuitenkin vain $1 \%$ vähemmän satoa kuin varsinaiset F1 -hybridit. Sadonalennus toisessa sukupolvessa ei ollut vielä merkittävä, sillä Syn2sukupolven lajikkeet tuottivat vain noin 2-3 \% pienemmän sadon kuin F1-hybridit. Falk jatkoi vertailua ja havaitsi myöhemmin (Falk 1994) hybrideillä edellisiä tuloksia pienemmät heteroosivaikutukset, keskimäärin vain noin $13 \%$. Vuosittain vaihtelevat olosuhteet vaikuttivat tuloksiin, sillä jatkaessaan edelleen tutkimusta useana vuotena Falk (1998) havaitsi joinakin vuosina vanhempaislinjojen tuottavan yhtä hyvän sadon kuin F1-hybridit ja synteettiset. Jonakin toisena vuotena erilaisissa oloissa ero saattoi olla kuitenkin noin $25 \%$ hybridien ja synteettisten eduksi.

Synteettisten lajikkeiden jalostuksessa voidaan käyttää valintamenetelmänä vastavuoroista jatkuvaa valintaa (reciprocal recurrent selection). Vastavuoroinen jatkuva valinta tähtää heteroosin kasvattamiseen parantamalla vanhempaislinjojen keskinäistä periyttämiskykyä. Edellytyksenä menetelmän käytölle on, että populaatioiden sisällä on geneettistä vaihtelua ja populaatioiden välillä on jo ennestään havaittu heteroosivaikutusta. Populaation yksilöiden periyttämiskyky toisen populaation yksilöiden kanssa määritetään ja uusi populaatio muodostuu parhaan periyttämiskyvyn omaavista yksilöistä. Uudet populaatiot ovat jo aikasempaa sopeutuneempia risteytymiseen ja menetelmän todellinen hyöty saadaankin muodostamalla uusista populaatiosta synteettinen lajike. Menetelmä on kehitetty alun perin maissinjalostajien toimesta palvelemaan hybridilajikkeiden tuotantoa, mutta sitä voidaan käyttää myös rypsin jalostuksessa.

Tutkimuksen tavoitteena oli löytää sellaisia kevätrypsipopulaatioita, joiden välillä havaittaisiin heteroosivaikutusta. Myös populaatioiden geneettisen etäisyyden ja heteroosin yhteyttä rypsillä 
haluttiin selvittää. Ajatuksena oli, että hitaista ja kalliista periyttämistestausvaiheista voitaisiin päästä eroon ja komponenttien valinta voitaisiin tehdä pelkästään geneettisen etäisyyden perusteella.

\section{Aineisto ja menetelmät}

Tutkimukseen valittiin 10 eri kevätrypsipopulaatiota. Geneettisen etäisyyden maksimoimiseksi populaatiot valittiin: a) maantieteellisesti mahdollisimman kaukaisista lähteistä, Kanadasta, Ruotsista, Skotlannista sekä Suomesta, b) geneettiseltä taustaltaan mahdollisimman erilaisista alkuperistä. Populaatiot pop1-5 ovat kaikki Suomessa jalostettuja kevätrypsilinjoja tai -lajikkeita. Siitä huolimatta kaikki edustavat erityyppisiä rypsilinjoja: popl edustaa rasvahappokoostumukseltaan poikkeavaa linjaa, рор 2 on laajassa viljelyssä oleva lajike, рор3 taas on Kanadan markkinoita varten jalostettu kalkkihomeenkestävä jalostuslinja , pop4 on erityisen vahvavartinen ja laonkestävä linja. Pop5 valittiin mukaan hyväksi havaitun periyttämiskykynsä mukaan. Ulkomaisista populaatioista pop6 edustaa Skotlannissa jalostettua materiaalia, pop7 ruotsalaista materiaalia sekä populaatiot pop8, pop9 ja pop10 edustavat kanadalaista rypsimateriaalia.

Jokaisesta populaatiosta kasvatettiin 10 kasviyksilöä populaatioiden ja yksilöiden geneettisen etäisyyden määrittämiseksi. Heteroosivaikutuksen arvioimiseksi geneettisen etäisyyden perusteella valitut yksilöt risteytettiin. Risteytyksiin valittiin vain kolme populaatioparia. Risteytyssiemenet kylvettiin kesällä 2003 pellolle pieninä ruutuina, joista jokaisesta kerättiin syksyllä 15 yksilöä sadonmääritystä varten. Heteroosin ilmenemisen osoittamiseksi myös vanhempaispopulaatioista kylvettiin ruudut pellolle.

\section{Tulokset ja niiden tarkastelu}

\section{Eri alkuperää edustavien populaatioiden geneettiset etäisyydet}

Kotimaista alkuperää olevat populaatioiden keskinäinen geneettinen etäisyys ei poikennut merkittävästi etäisyydestä, joka määritettiin niiden ja ulkomaista alkuperää olevien populaatioiden välille (Taulukko 1.). Hieman yllättäen niiden geneettinen etäisyys toisiinsa nähden oli hieman suurempi kuin ulkomaisten populaatioiden keskinäinen geneettinen etäisyys, vaikka ulkomaisten populaatioiden jalostaja oli lähes kaikilla eri.

Populaatio pop5 poikkeaa geneettisesti eniten muista mukana olleista kevätrypsipopulaatioista. Suurin etäisyys $(3,47)$ havaittiin pop2:n ja pop5:n eli kahden kotimaisen populaation välillä. Pop2 on geneettisesti epäyhtenäisin kaikista populaatioista. Sen yksilöiden välinen geneettinen etäisyys on keskimääräisesti suurempi $(3,32)$ kuin muiden populaatioiden eri yksilöiden välinen etäisyys. Geneettisesti kaikkein läheisimpiä ovat suomalaista alkuperää oleva pop4 ja Skotlannista hankittu pop6.

Taulukko 1. Kevätrypsipopulaatioiden keskimääräiset geneettiset etäisyydet (euklidinen etäisyys) 36 bandin mukaan analysoituna.

\begin{tabular}{|c|c|c|c|c|c|c|c|c|c|c|}
\hline Pop1 & 2,62 & & & & & & & & & \\
\hline Pop2 & 3,28 & 3,32 & & & & & & & & \\
\hline Pop3 & 2,97 & 3,27 & 2,58 & & & & & & & \\
\hline Pop4 & 2,94 & 3,16 & 3,09 & 2,95 & & & & & & \\
\hline Pop5 & 3,25 & 3,47 & 3,35 & 3,22 & 3,08 & & & & & \\
\hline Pop6 & 2,75 & 3,11 & 2,88 & 2,84 & 3,14 & 2,60 & & & & \\
\hline Pop7 & 3,24 & 3,21 & 3,17 & 3,10 & 3,17 & 3,13 & 3,06 & & & \\
\hline Pop8 & 3,19 & 3,28 & 3,14 & 3,04 & 3,24 & 3,06 & 3,12 & 3,06 & & \\
\hline Pop9 & 3,14 & 3,38 & 3,29 & 3,17 & 3,25 & 3,00 & 3,21 & 3,10 & 2,89 & \\
\hline \multirow[t]{2}{*}{ Pop10 } & 3,03 & 3,24 & 3,14 & 3,04 & 3,30 & 2,80 & 3,27 & 3,11 & 3,15 & 2,81 \\
\hline & Pop1 & Pop2 & Pop3 & Pop4 & Pop5 & Рорб & Pop 7 & Pop8 & Pop9 & Pop10 \\
\hline
\end{tabular}

\section{Heteroosin ilmeneminen}

Kasvuolot vuonna 2003 olivat kuivat ja kuumat, jotka heijastuivat kevätrypsien sadontuottokykyyn. Kukinta-ajan korkea lämpötila ja kuivuus haittasivat rypsin pölyttymistä ja lituja muodostui huomattavan vähän. Tämä ilmeni erityisesti myöhäisillä populaatioilla. Lohkolla esiintyneen 
voimakkaan olosuhdevaihtelun vuoksi jouduttiin sato huomioimaan ainoastaan kahden populaatioparin hybridisadosta.

Populaatioparin pop4 x pop6 yksilöparien hybrideistä $29 \%$ tuotti merkitsevästi suuremman sadon kuin paras vanhempaispopulaatio. Noin $53 \%$ niistä tuotti suuremman sadon kuin heikkosatoisempi vanhempaispopulaatio. Vanhempiaan heikomman sadon tuotti ainoastaan $12 \%$ hybrideistä. Käytettäessä pop6:n yksilöitä emokasveina tilanne ei muuttunut olennaisesti. Suuremman sadon kuin paras vanhemmista tuotti $25 \%$ hybrideistä ja heikkosatoisempaa vanhempaa enemmän satoa tuotti $50 \%$ jälkeläistöistä. Yksikään niistä ei tuottanut huonompaa satoa kuin vanhempansa.

Populaatioparilla pop1 x pop9 ei heteroosivaikutus ollut yhtä selvä populaatioparilla pop4 $\mathrm{x}$ pop6. Ainoastaan $14 \%$ hybrideistä tuotti suuremman sadon kuin paras vanhemmista ja $21 \%$ paremman sadon kuin heikkosatoisempi vanhempi. Pop9:n ollessa emona (Pop9 x Pop1), $7 \%$ hybrideistä tuotti suuremman sadon kuin paras vanhemmista ja $21 \%$ tuotti suuremman sadon kuin heikosatoisempi vanhemmista.

\section{Geneettisen etäisyyden yhteys satoon}

Geneettisellä etäisyydellä ei ollut niin selvää ja voimakasta yhteyttä kevätrypsihybridien satoon kuin odotettiin. Ainoastaan yhdellä vanhempaispopulaatioparilla pop4:n ollessa emona havaittiin lineaarinen yhteys vanhempien geneettisen etäisyyden ja jälkeläisten sadontuottokyvyn välillä (Kuva 1.). Pop4 ollessa pölyttäjänä ilmiö ei enää esiintynyt. Myöskään popl ja pop9 jälkeläistöillä ei mitään yhteyttä vanhempien geneettisen etäisyyden ja sadontuoton välillä havaittu.
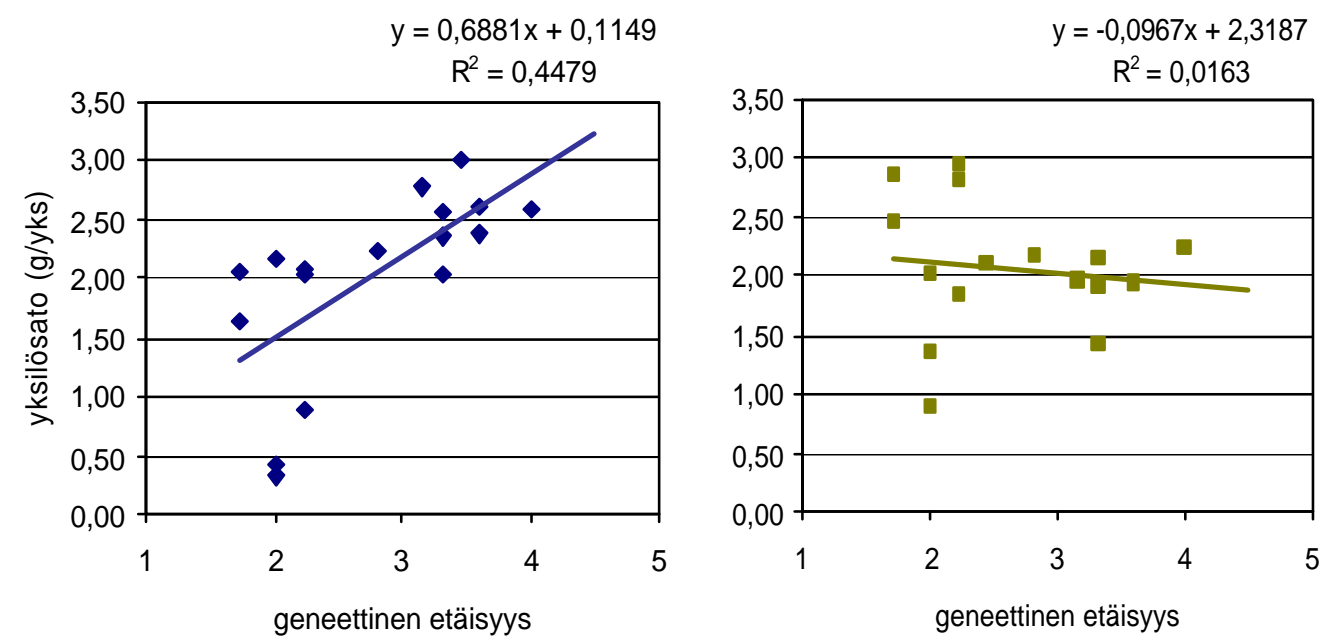

Kuva 1. Geneettisen etäisyyden vaikutus kevätrypsiyksilöiden satoon, vasemmalla pop4 x pop6 ja oikealla pop6 $\mathrm{x}$ pop4.

\section{Johtopäätökset}

Populaatioiden vähäiset geneettiset erot tutkimuksessa kuvaavat hyvin 90-luvulla käytettyä jalostusaineistoa. Laatuvaatimukset lajikkeille ovat olleet yhteneväiset koko rypsinviljelyalueelle. Erukahapottomuuden vaatimus pakotti jalostajat käyttämään samaa geenilähdettä, jolloin rypsin geneettinen muuntelu on kaventunut huomattavasti. Se kuvaa myös jalostajien välillä vallinnutta voimakasta materiaalivaihtoa.

Havaitut sadonparannukset osoittivat heteroosivaikutuksen hyödyntämismahdollisuuden. Samalla ne kuitenkin osoittivat vanhempaislinjojen valinnan tärkeyttä. Heteroosivaikutusta ei ole mahdollista aikaansaada millä tahansa komponenteilla. Vanhempien valinnassa ei kuitenkaan voida yksinomaan luottaa pelkästään geneettiseen etäisyyteen. Periyttämiskykyä mittaavat testiristeytykset ja kenttäkokeet ovat välttämättömiä maksimaalisen heteroosin löytämiseksi.

Kehittämällä jalostusmenetelmää yhä edelleen ja keskittymällä oikeiden vanhempaispopulaatioiden valintaan voidaan synteettisillä kevätrypsilajikkeilla saavuttaa hybridilajikkeiden edut. 


\section{Kirjallisuus}

Becker H.C. 1989. Breeding of synthetic varieties in partially allogamous crops. Eucarpia, Proc. XII Congress 27. Feb to 4. Mar, Göttingen, Germany. Pp.81-90.

Falk K.C, Rakow G.F.W, Downey R.K. 1998. The utilization of heterosis for seed yield in hybrid and synthetic cultivars of summer turnip rape. Can. J. Plant Sci. 78: 383-387.

Falk K.C, Rakow G.F.W, Downey R.K., Spurr D.T. 1994. Performance of inter-cultivar summer turnip rape hybrids in Saskatchewan. Can. J. Palnt Sci. 74: 441-445.

Gallais A. 1988. Heterosis: its genetic basis and its utilization in plant breeding. Euphytica 39: 95-104.

Schuler T.J., Hutcheson D.S., Downey R.K. 1991. Heterosis in intervarietal hybrids of summer turnip rape in western Canada. Can. J. Plant Sci. 72: 127-136.

Sernyk J.L., Stefansson B.R. 1983. Heterosis in summer rape (Brassica napus L.) Can. J. Plant Sci. 63: 407-413 